\title{
Impact of Industrial Estates on Water Resources
}

\author{
Richa Maheshwari
}

\begin{abstract}
Last few decades have seen a boom in the industrial sector in India. This industrialization helped people in getting employment but we cannot underscore the pollution these industries are generating on our so called "healthy" environment. This pollution has impacted our prime natural resources like Air, Water and Land and thus has resulted in the obvious deterioration of our flora, fauna and human health. In the following paper, I have taken an industrial estate complex comprising of three industrial estates; Naroda, Odhav and Vatva, situated in one of the most polluted cities of Gujarat, Ahmedabad.

The study provides an understanding of the chronology of events that took place since 1960 till 2014 within and around the three estates, assessing and evaluating the quality of water resources impacted by these industrial estates and identifying the environmental and socio-economic impacts of these industrial estates on water resources. The paper ends by providing some alternative/ supplementary solution in order to enhance the quality of wastewater.
\end{abstract}

Index Terms - Industrial estates, water pollution, Sabarmati river, kharicut canal.

\section{INTRODUCTION}

Industrialization is necessary for economic development of a country. It is essential to fulfill the growing needs of the mankind, yet it is taxing on the natural resources which are the very basis of our existence.

When industrialization was at its minimal, the natural resources like air, land and water were in their pristine conditions and habitual for all living organisms. Even the resilience properties of nature and its resources were able to maintain their quality. Gradually industrialization paced up and with its shooting up, growth in economy was registered that paved way to employment opportunities and better standard of living. Initially it started to meet the needs of people by providing them with necessary products and goods but eventually it was observed that this is happening at the cost of our environment.

In the past few decades, even Gujarat state in India has earmarked boom in industrial development, originally as textile industries that later got diversified into industries in varied areas such as metal products, machinery, plastics, electronics, pharmaceutical, passenger cars, engineering, electrical appliances etc., to name a few. At present, there are nearly 1200 large industries and 3,45,000 micro, small and medium scale industries. These industrial estates have been established by Gujarat Industrial Development Corporation (GIDC), a government authority which operates, maintains and develops the industrial estates by providing the

Manuscript received October 18, 2015; revised February 28, 2016.

Richa Maheshwari is with Centre for Environmental Planning and Technology, India (e-mail: richapm277@gmail.com). industrialists with developed plots, necessary infrastructure facilities and built-up sheds. There are in all 252 industrial estates in Gujarat state, out of which 11 are located in Ahmedabad, the largest districts in the state [1].

Within Ahmedabad city, there are three major industrial estates namely Naroda, Odhav and Vatvaon the eastern side of the city, as demarcated in Figure 1. These were established in 1970's in the suburban areas of the then Ahmedabad city that was gradually engulfed by the growing city.

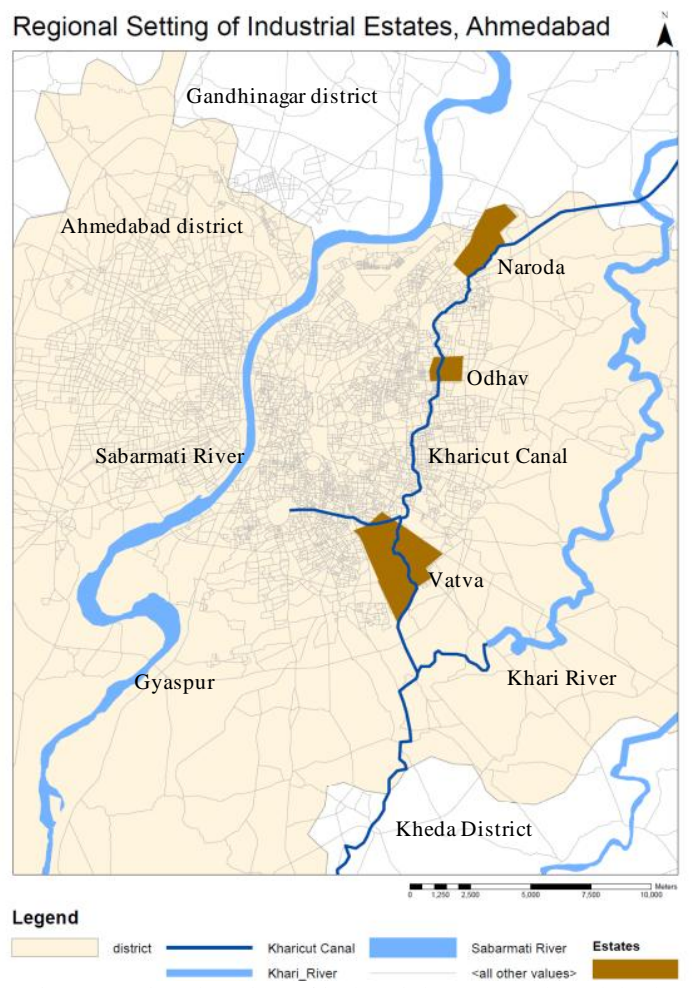

Fig. 1. Regional setting of industrial estates, Ahmedabad.

Ahmedabad has witnessed the wrath of the polluting industries, as initially there was no law for protecting the environment. No concept of safeguarding the prime natural resources existed amongst the government or public. Also there was no awareness for the same and collaterally, economic growth always remained the priority for the government and environment took a back seat.

So, the aim of my study is "To identify the impact of industrial estates on water resources and provide some alternative/ supplementary solutions". To accomplish this, the objectives are as follows:

1) To study the profile of each estate in context to water resource.

2) To assess the water quality of - Kharicut canal and Sabarmati river.

3) To identify the environmental and socio-economic impact of industrial estates on water resources in the affected village. 
4) To propose and enhance the existing wastewater treatment mechanism.

\section{BODY}

In the three estates in Ahmedabad city, in the past, due to the absence of awareness and sensitivity towards the environment, the industries started discharging their untreated wastewater directly into Kharicut canal which was easily accessible. Kharicut canal was constructed 110 years ago for drinking water and irrigation facilities on outskirts of Ahmedabad district. It extended in two districts - Ahmedabad and Kheda. Around 42 villages and 10 lakes were dependent upon water flowing in Kharicut canal. Two season crops were harvested with help of water of Kharicut canal especially rice harvesting. Due to the discharge of untreated wastewater into the canal, the water got mixed with chemicals and heavy metals which were unfit for the use in irrigation and for animals and household chores.

Thus on one hand the industrial development increased and on the other the water resources were getting abused. In order to combat this, in 1974 Water (Prevention and Control of Pollution) Act was introduced which was aiming at improving and safeguarding the water resource. However, even after the enforcement of such an act, the industrialists continued to contaminate and degraded the water resources. They discharged their untreated industrial wastewater into the Kharicut canal until the canal water reached a limit and became saturated from taking more effluents. It was now that the detrimental effects started to register when

1) The acidic and toxic untreated industrial wastewater overflowed into the surrounding residential areas and people started complaining.

2) The farmers who were dependent on the canal water for irrigation purpose started complaining of the colored \& foul smelling water coming to their agricultural fields \& affecting their crops as well as their cropping pattern.

3) Moreover, the Industrial effluents contaminated the ground water up to $183 \mathrm{~m}$ in depth and the bore wells started giving colored \& foul smelling water. It began to create health \& hygiene problems for people.

Local villagers when confronting such a deadly scenario filed a PIL in 1995 to the High Court against such malpractices. The Hon'ble High Court in 1997 gave its judgment and implemented the Polluter Pays Principle on major industries for causing pollution and damage to the agricultural fields. Moreover they also asked the factories to establish Common Effluent Treatment Plants (CETP) in each estate to treat the toxic and acidic wastewater. Adhering to the judgment, by 1999 CETPs were installed along with the establishment of mega pipeline in 2000. The mega pipeline was laid to convey the wastewater from Naroda industrial estate to Vatva industrial estate via Odhav industrial estate and finally discharging it into Sabarmati River at Gyaspur.

But even today the issue of water pollution is continuing. This paper primarily looks into the legal and illegal systems by which the water gets contaminated and leads to its cascading effects of the same. The legal system focuses on the water quality report of CETPs by Central Pollution Control Board (CPCB) and of Sabarmati River by Gujarat State
Pollution Control Board (GPCB) whereas the illegal system focuses on describing the malpractices by the defaulters on Kharicut Canal.

TABLE I: OUTLET READINGS FOR 2009, CPCB

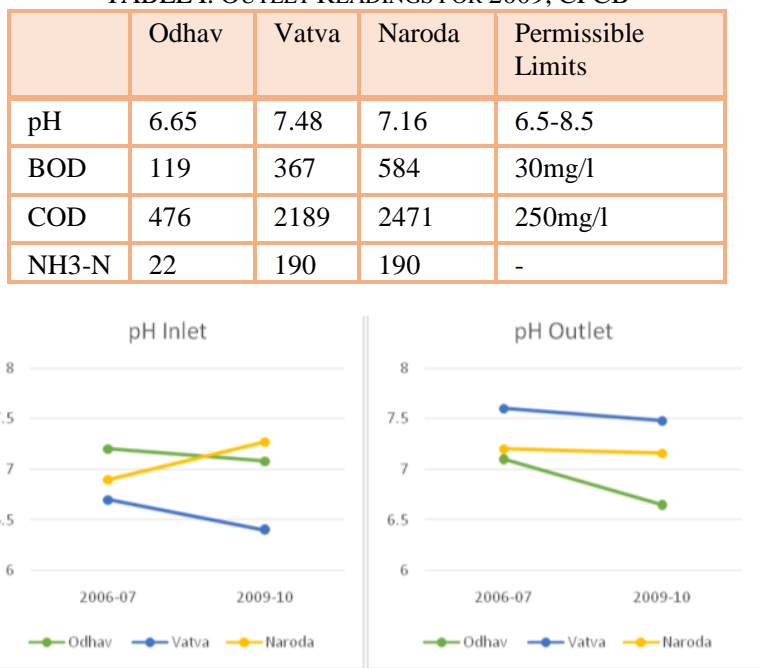

Fig. 2. Inlet and outlet $\mathrm{pH}$ readings for 2 years.

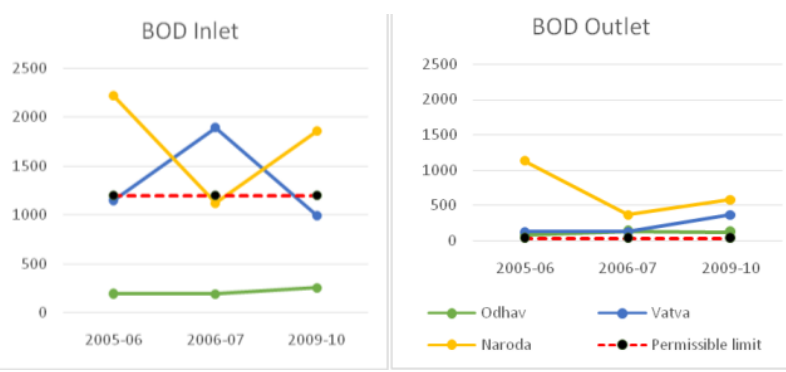

Fig. 3. Inlet and outlet BOD readings for 2 years.

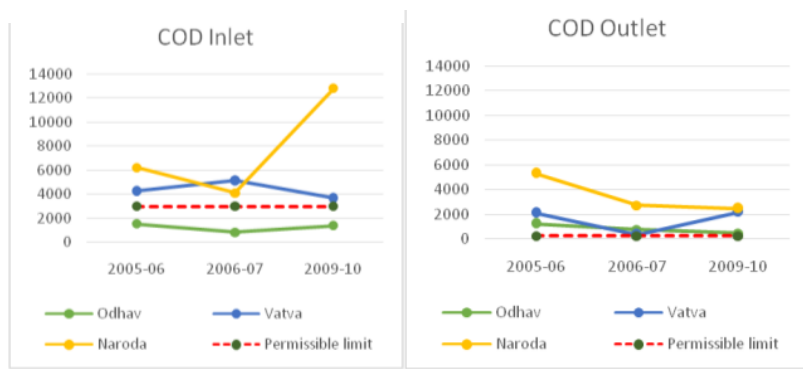

Fig. 4. Inlet and outlet COD readings for 2 years.

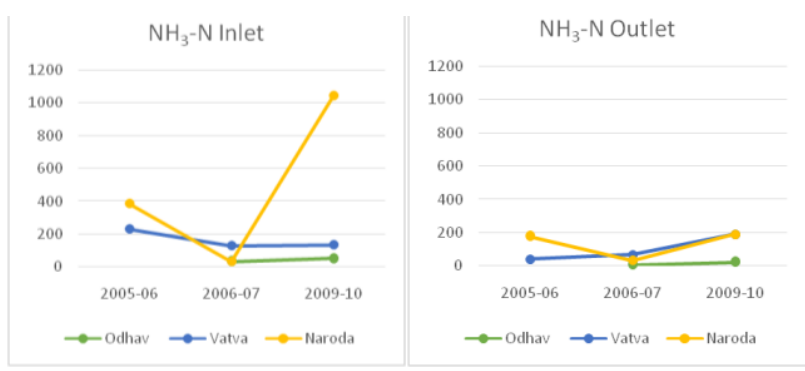

Fig. 5. Inlet and outlet NH3-N readings for 2 years.

Legal System: The legal system describes the wastewater quality report of Common Effluent Treatment Plant (CETP) (as shown in Table 1) and Sabarmati River. The CETP reports stated that the quality of wastewater generated out is not complying with the norms set by Central Pollution Control Board (CPCB) and Gujarat Pollution Control Board (GPCB). The concentration of major parameters of like BOD (Biological Oxygen Demand), COD (Chemical Oxygen Demand), $\mathrm{pH}$ (Potential of Hydrogen), and NH3-N 
(Ammonia Nitrogen) for the year 2005, 2006and 2009 for all three estates hardly matches or adheres the permissible limit as seen in the Figures 2, 3, 4, and 5.

The BOD and COD readings are above the permissible limits. This shows that the treated wastewater is also polluted water which contains high amount of toxic and acidic matters. Moreover across all the three estates, the readings at Naroda and Vatva Industrial Estate are found to be dreadful. Even though these estates contributes $17 \%$ and $77 \%$ of the total wastewater generated respectively, the parameters have high values in all the years which indicate that the CETP at Naroda and Vatva is in a bad shape and it hardly meets the limit at some period of time.

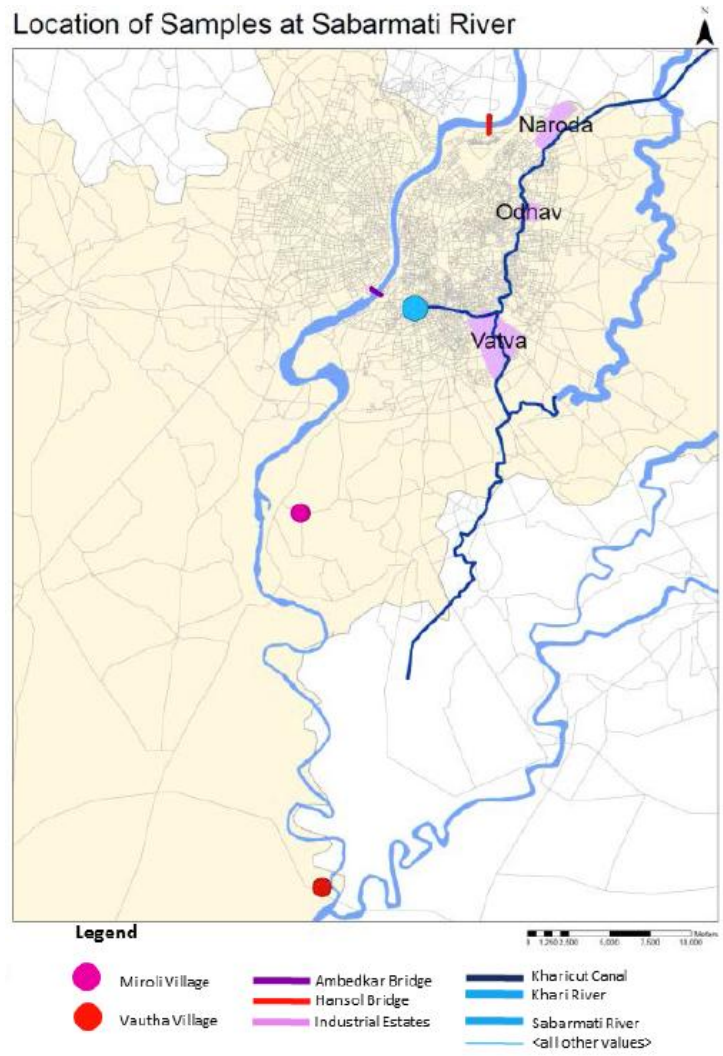

Fig. 6. Location of samples at Sabarmati river, Ahmedabad.

To assess the water quality of Sabarmati River, another study was undertaken by Gujarat Pollution Control Board (GPCB), mentioned in its annual report. They critically analyzed and compared the quality of water by studying the major parameters like $\mathrm{pH}, \mathrm{BOD}, \mathrm{COD}$ and $\mathrm{DO}$ from four different locations namely Hansol Bridge, Ambedkar Bridge, Miroli Village and Vautha Village as shown in Figure 6. Hansol is the upstream whilst Vautha is the downstream of Sabarmati River in Ahmedabad city. In order to geta comparative analysis of the concentration levels, the samples were studied from 2004 till 2014. The key findings of the report are as under:

1) The concentration of $\mathrm{pH}$ and Do decreases from upstream to downstream which shows that the water quality is deteriorating. Decrease in $\mathrm{pH}$ indicates that the water slowly turns towards being acidic in nature.

2) The value of BOD and COD increases which indicates that the quantum of pollution in the river water increases because of the tremendous concentration of toxic and acidic substance. Thus from upstream to downstream, the level of pollution increases.

3) At Ambedkar Bridge and Miroli, the quality of water is highly polluted because the so called treated industrial wastewater gets discharged via the mega pipeline at Gyaspur; which is below Ambedkar Bridge and above Miroli.

4) When the river water reaches Vautha, the concentration of these parameters changes and shows a slight improvement as compared to Miroli readings. This is because the concentration of these parameters decreases when they get dissolved with river water.

5) Among all the readings, there can be slight variations in the concentration levels across the years because either the month of the sample collection is different year-wise or the dilution factor could be different [2].

Thus the Sabarmati River water quality degrades from Hansol to Vautha as shown in Fig. 7-Fig. 10.

$\mathrm{pH}$

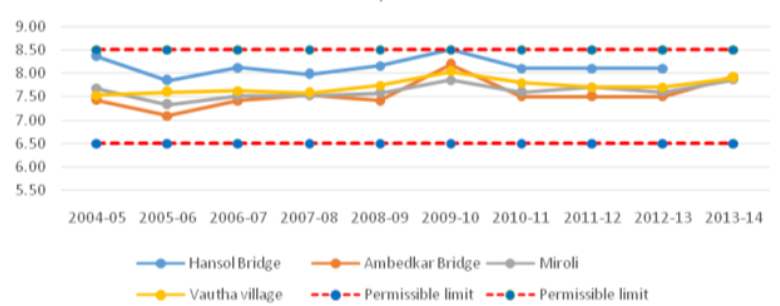

Fig. 7. pH readings across year for 4 locations.

DO

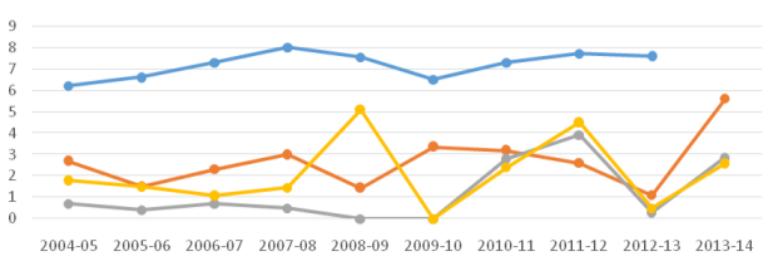

$\rightarrow$ Hansol Bridge $\rightarrow$ Ambedkar Bridge $\rightarrow$ Miroli $\rightarrow$-Vauthavillage

Fig. 8. DO readings across year for 4 locations.

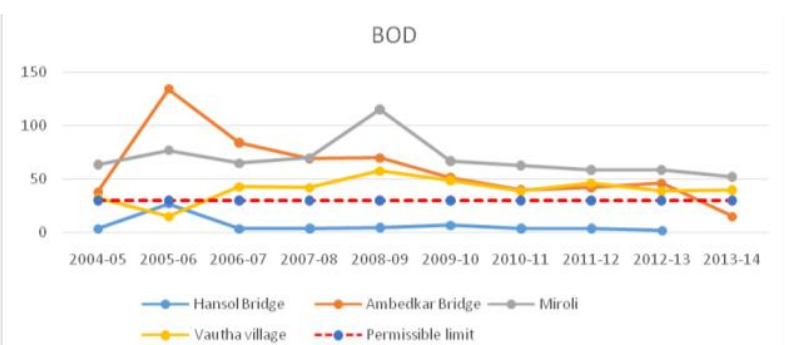

Fig. 9. BOD readings across year for 4 locations.

COD

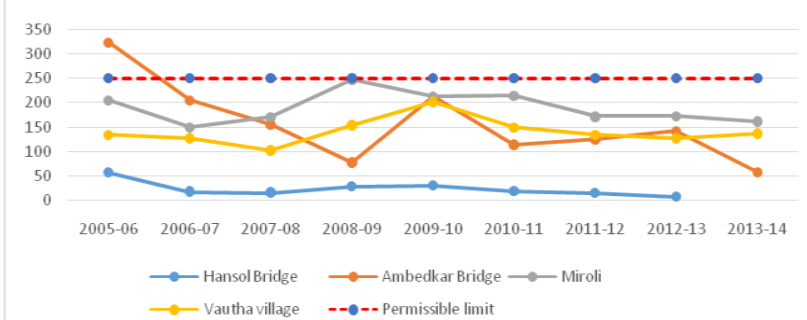

Fig. 10. COD readings across year for 4 locations.

At Gyaspur, the partly treated industrial effluents are discharged through the mega pipeline. They are highly toxic in nature because of the following reasons:

1) The waste water discharged from the CETPs does not comply with the standards. 
2) There are industries that connect their untreated wastewater pipeline illegally with the mega pipeline as shown in Fig. 11.

3) It seems that the authorities are not functioning properly.

4) Dumping of untreated wastewater directly into the river through tankers at night.

5) Releasing untreated wastewater into the river.

6) Overflow of mega pipeline because of illegal sewage connections [3].

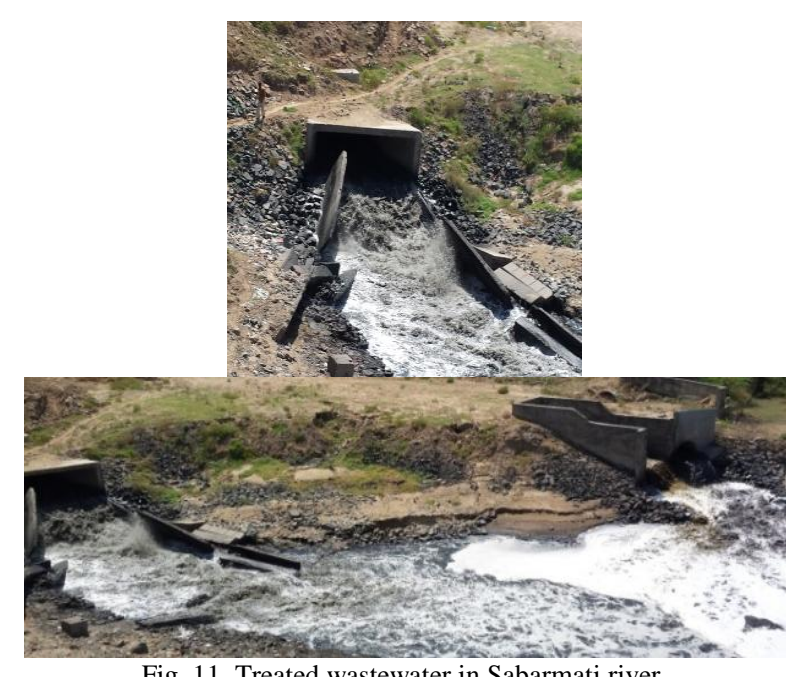

Fig. 11. Treated wastewater in Sabarmati river.

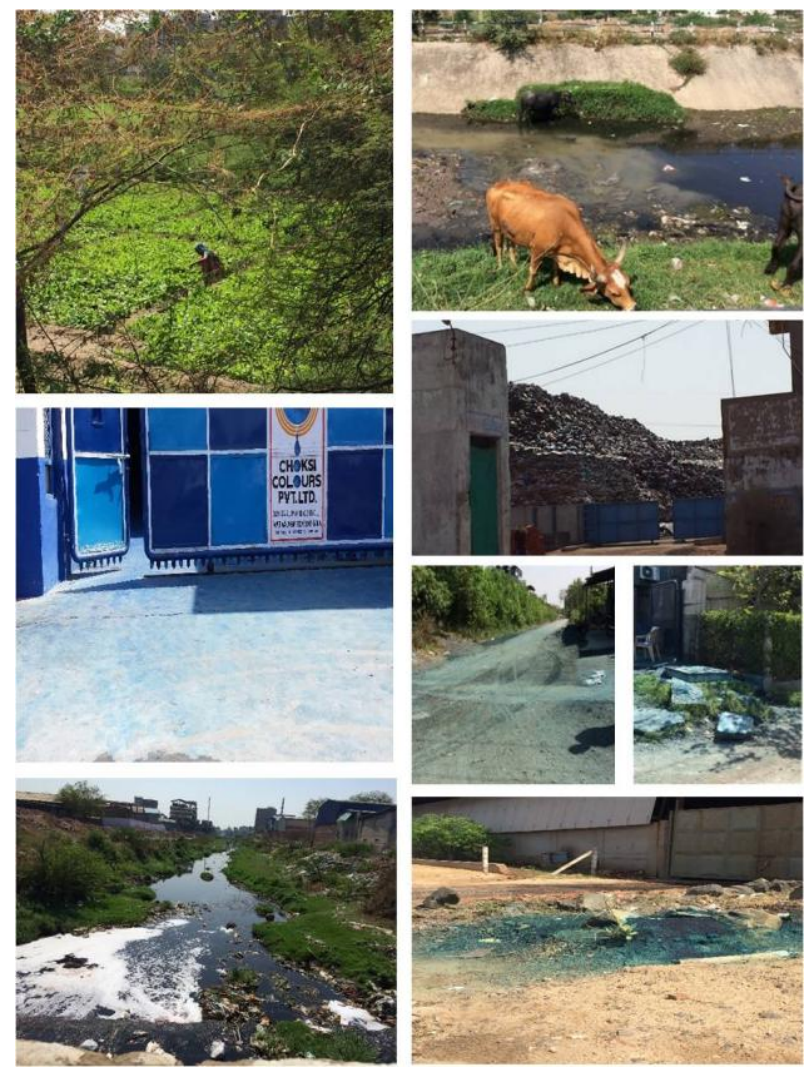

Fig. 12. Impact of treated wastewater on biotic and abiotic factors

Therefore the legal system is neither operating efficiently nor meeting the norms set by GPCB.

Illegal system: After establishment of CETPs and mega pipeline, it was presumed that Kharicut canal would be free of industrial effluents. Kharicut canal passes by Naroda then Odhav and before coming to Vatva, it splits and one of the branches goes to Chandola Lake. Since Odhav and Naroda industrial estates are smaller in size and less polluting as opposed to Vatva, the water in Kharicut canal seems to be less polluted before the bifurcation. But the branch that comes to Vatva is highly polluted since it passes through phase 2 and 4 of Vatva industrial estates which have a major concentration of chemical and heavy metals respectively. This is due to illegal discharge of toxic effluents into the Kharicut canal.

Hence the inefficiency of legal systems and illegal practices has degraded and contaminated the water resources which lead to dreadful impacts on man, flora and fauna as shown in Fig. 12 [4].

Such impacts have been highlighted in a study undertaken jointly by Institute for Studies and Transformation and Youth for Unity \& Voluntary Action. It carried out surveys in 9 affected villages in the downstream of Sabarmati River and found that the presence of heavy metals and organic and inorganic matter leads to various alarming impacts on health, livelihood and environment.

The key findings of the study are as follows:

1) Almost $90 \%$ of crops grown in these villages are irrigated by Sabarmati.

2) Around $40 \%$ of farmers use bore-well water, which also appears contaminated.

3) Many diseases have been reported in the Livestock like Chakri, Afri and Gal Sutha.

4) Death of calves half way through the pregnancy period.

5) Milk production dropped drastically.

6) Fat content gone down

Many information floated regarding the degradation of the river water quality because of these three industrial estates in the newspaper, articles and news.

Thus the contaminated water degrades the quality of soil because of intrusion of heavy metals, chemical runoff from industries and salinity. It deteriorates the quality and quantity of agriculture. Quality degradation leads to diseases to humans and animals which may turn out to be detrimental over the years whereas quantity degradation leads to lower crop yield, reduces seed germination and changes the cropping pattern. Contaminated water also impacts the biodiversity. On one hand, it leads to inhibition of plant growth, reduction in cell activities and death of plants and on the other it affects the animals mainly livestock and fish. In livestock, the yield of milk reduces, milk quality degrades and further it may turn out to be detrimental.

All these components of environment indirectly hamper the socio and economic well-being of people. In terms of social impact, there is loss of potable water, high cost of treatment of water, high cost of medical treatment because of calling of many diseases, loss of aesthetic value, loss of recreational areas, stretches emanating bad smell, reduction in marriage proposals in girl families and may lead to death of humans and animals. In terms of economy, it leads to loss of agricultural lands, loss of agricultural production, loss of fishery production and loss in milk production. Fig. 13 describes the direct and indirect impacts of contaminated water in brief.

Since past 40 years, there has been no significant improvement in the quality of wastewater discharged into the Sabarmati River. So, a time has come when it has become very essential to supplement the existing treatment system by intervening into it and enhance the water quality, change the 
perception of wastewater from a problem to wastewater as a resource.

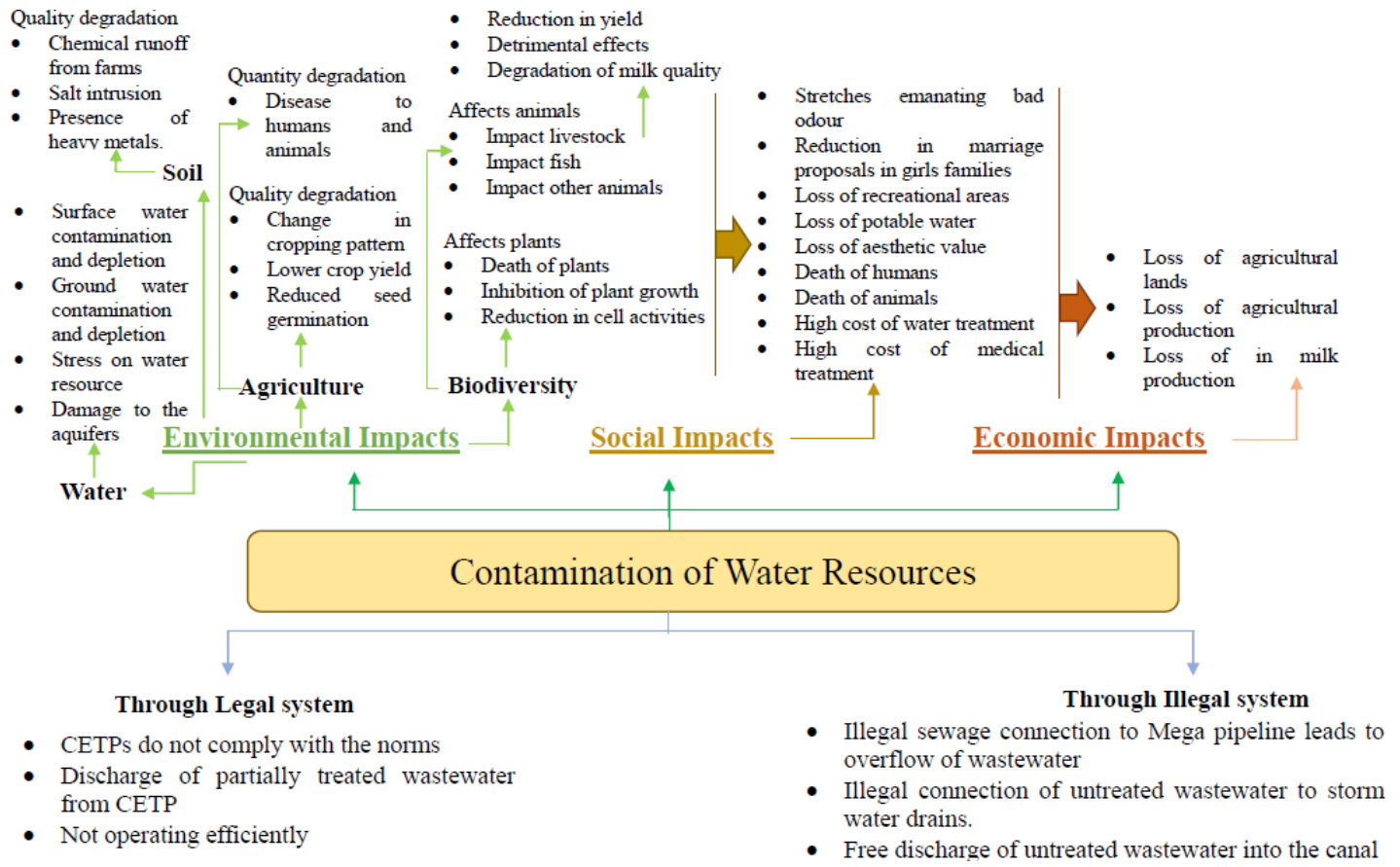

Fig. 13. Problem tree analysis.

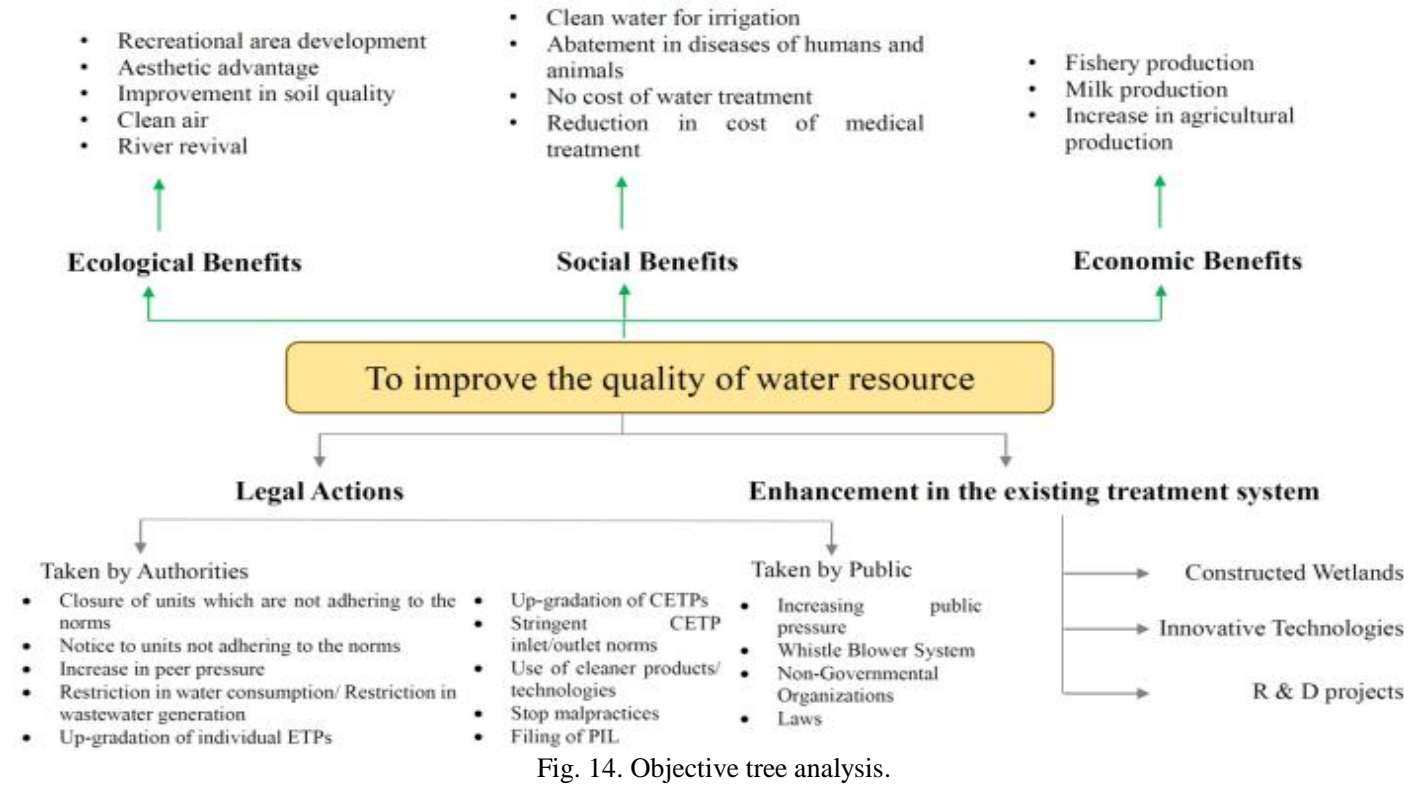

To avoid such risky situations, it is recommended either to take some legal actions by the authorities on the defaulters, actions by public on the defaulters or to treat the wastewater using innovative methods as shown in Fig. 14.

Legal actions by the authorities against the defaulter could be like; Closure or notice to the units which are not adhering to the norms, increase in peer pressure, restriction in water consumption/ restriction in wastewater generation, up-gradation of individual ETPs, up-gradation of CETPs, stringent CETP inlet/outlet norms, use of cleaner products/ technologies and to stop malpractices. But the most important thing of all is that the CETPs should be operated by technical and professionals and all non-technical staff should be removed off. Moreover, the ETPs should also be operated by professionals who shall be reported directly to the top management.

To combat the problem of contamination of water resources, public participation can also play a key role. Whistle Blower System was implemented which meant to involve public in mitigating pollution. According this system, person who provides information about industries releasing effluent illegally will be awarded. This system was executed from 1st December, 2005. But the system failed to execute properly due to lack of awareness among the public about Whistle Blower System.

Non-Governmental Organizations are also looking towards safeguarding and protecting our natural resources. They raise complaints against the insensitivity of factory to burn the environment.

Laws are also enacted for safeguarding and protecting the environment. Under Article 51-A (G), it shall be the responsibility of each citizen of India to protect and improve the natural environment including lakes, forests, lakes, wild life and to have compassion for living creatures. The efforts \& 
responsibilities of guarding the environment was provided legal framework with enactment of Water (Prevention \& Control of Pollution) Act, 1974 and thus came The Environment Protection Act in 1986. Hence these are the ways in which public can involve itself in protecting their environment.

However, it is also possible to intervene in the existing wastewater treatment mechanisms by either supplementing the existing system by segregating the homogenous wastewater at source only and then allowing it to go in the CETP or by enhancing the existing treatment system which means that incorporating more steps in the treatment process or by augmenting the existing treatment system which means using innovative technologies like constructed wetlands or multiple effective incinerators.

In this paper, I have proposed a pilot scale project of Constructed Wetlands which will further treat the wastewater and then discharge it into Sabarmati River. An understanding of wetlands was gained by carrying out literaturestudies, wherein this cost efficient and environmentally sound system of constructed wetland was incorporated and proved to be a success.

The pilot project has been proposed under the five stages.

Stage 1: To identify the quality and quantity of wastewater generated from the three industrial estates.

Stage 2: To assess the area requirement

Stage 3: To carry out Land Suitability Analysis using the principles of Ian McHarg

Stage 4: Treatment Mechanisms

Stage 5: End gains

Through land suitability analysis, it was deduced that the area in Gyaspur has ample amount of waste land available as shown in Fig. 15, which could be used to establish the constructed wetland for the pilot project. Here 1 MLD of treated wastewater that comes from the CETP would further be treated within an area of $1.05 \mathrm{Ha}$ as per the land requirement assessment. Thus the proposed constructed wetland can come near the outfall and allow the treatment process of wastewater which will essentially drain into Sabarmati with better quality. The risk involved is minimum with almost no loss but has unlimited benefits and application of such a treatment method will be cost effective and will require low maintenance also.

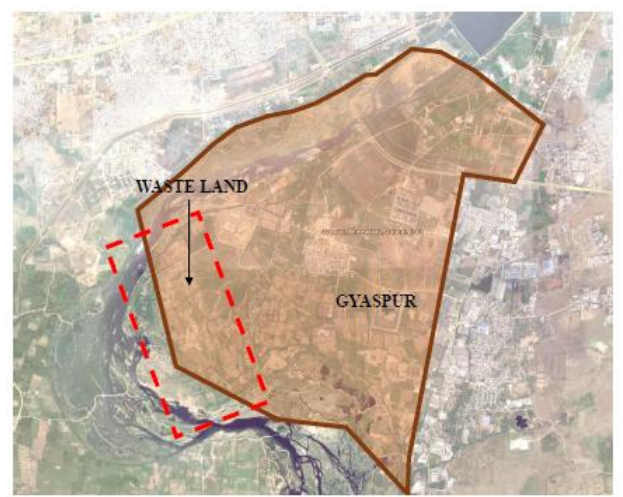

Fig. 15. Availability of wasteland at Gyaspur which is suitable for constructed Wetlands.

The wetland aid in removing the metals, phosphorous, nitrogen, chemical oxygen demand, biological oxygen demand, suspended solids and pathogens from the wastewater and essentially improves the quality of river water. This improved water when used by man and animals improves their health and hygiene. There could be thus various ecological, social and economic benefits. The ecological benefits would be recreational area development, aesthetic advantage, clean air, river revival and improvement in soil quality. The social benefits would be clean water for irrigation, abatement in diseases, low cost of water treatment and reduction in cost of medical treatment while the economic benefits would be increase in agricultural production, milk production and fishery production [5].

\section{CONCLUSION}

Sprouting industrialization has created a deplorable impact on environment. It has become an awful reality that even though promising industrial units, both large and small, provide employment opportunities, they also pollute and degrade the environment. This pollution is damaging the entire gamut of our environment including air, water and land, and has a cascading impact on our biotic and abiotic factors. However in the process of industrialization, water has remained a key resource as it is used in almost all kinds of manufacturing processes and simultaneously has impacts registered on humans, flora and fauna sooner than any other resources.

Gujarat has earmarked a colossal growth in industriesand has invited enormous investments from across the globe which essentially had contributed for the growth of industries in Ahmedabad, predominantly in the three GIDC estates viz Naroda, Odhav and Vatva post 1970. These industrial units have been emanating pollution that has had grave impact on the residents living in the areas surrounding the GIDC belt. At that time there were no laws to safeguard environment, no concept existed among the government, industrialist or public and no awareness was there as it is today. Moreover, economic growth through industries was priority for the government. However, in absence of such laws, policies or awareness, these industrial estates started discharging untreated industrial waste into the Kharicut canal which persisted till the canal water could not dissolve anymore industrial waste. Achieving its limit, the canal water became saturated of dissipating the highly toxic and acidic untreated effluents. Unable of being absorbed by the canal water, the dangerous effect of this process began to show when these environmental fallouts remained unaddressed. It disturbed the socio and economic well- being of people by affecting their health and hygiene.

Hence, in 1997 to resolve this issue GPCB took vigilant actions against the defaulters and Hon'ble High Court gave its judgment which made the industrialist establish CETPs in all the three estates in 1999 . Followed by them, mega pipeline was laid in 2000 to convey the treated industrial wastewater from all the three GIDC and discharged them into Sabarmati River. But even today both the Sabarmati River and Kharicut Canal is facing the deplorable impacts of untreated wastewater into them. The situation is worsen and a high time has come when the as an individual and an authority we 
should react.

Apart from this, in the Constitution of India under Article 51 (A), it was stated that "It shall be the responsibility of each citizen of India to protect and improve the natural environment including forests, lakes, rivers and wild life, and to have compassion for living creatures". The responsibilities of guarding the environment were given legal framework with enactment of Water (Prevention \& Control of Pollution) Act, 1974.

A time has come when it should become obligatory to alter the perspective of wastewater as a problem and convert it into a resource by intervening into the harm caused. It can be done through certain approaches-either to take legal actions by the authorities on the defaulters, actions by public on the defaulters or to enhance the existing treatment system using innovative methods. Amongst the aforesaid approaches, the legal actions by authorities and public are implemented even today but because of lack of accountability, transparency and apathy, these malpractices have failed to stop. Therefore there is a need to supplement the existing treatment system; way to do is through constructed wetlands approach.

Henceforth, the above mentioned approaches if implemented and executed fairly, may aid improving the environment and hence water resources. Though they could be considered as baby-steps into the whole lot of pollution and degradation of environment, it will make its mark to achieve greater heights if implemented properly. A start is what it takes to revolutionize.

\section{REFERENCES}

[1] V. Gujarat. (2015). Investor Facilitation Portal Government of Gujarat. [Online].

Available:
[2] CPCB, Comprehensive Environmental Pollution Abatement Action Plan Ahmedabad Industrial Cluster, Gujarat, 2010.

[3] M. Pandya. Conterview.org. [Online]. Available: http://counterview.org/2014/03/19/survey-results-suggest-water-quali ty-of-sabarmati-has-very-high-pollutants-those-managing-it-are-violat ing-cpcb-norms/

[4] J. S. S. Mudrakartha, "Unclogging the Khari river," Economic and Political Weekly, p. 4, 2006.

[5] C. S. A. Kumar, "Constructed wetlands: An approach for wastewater treatment," Pollution, p. 7, 2011.

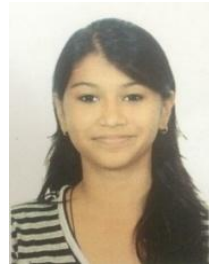

Richa Maheshwari was born on July 27, 1993 in India. In May 2015, she completed her bachelors in planning from Centre for Environmental Planning and Technology University (CEPT), Ahmedabad, Gujarat, India. In November 2011, she participated in regional school program conducted in Chachravadi village, Ahmedabad. The aim was to study the livelihood pattern of the people and the profile of different caste. In November 2012, she participated in regional school program conducted to Auroville, Pondicherry. The focus was on understanding and exploring different sustainability aspects and their implementations. In June 2013, she did an internship under M/s Prabhakar B Bhagwat, Ahmedabad for a month where she explored the condition of roads and how it responds to the urban areas. She has also done a study on parking and the problems related to it. The final outcome was in the form of a report. In November 2013, an exchange program was undertaken where on merit, she went to Cardiff University in Wales for studying Neighborhood Planning across Borders (UK and India). In May 2014, she did an internship with SLS Transport Training Institute and Consultancy Pvt. Ltd., Bangalore, India for two and a half months. The work done includes Station Accessibility Plan for a Metro Station, Freight Management and Redesigning of problematic junctions. In May 2015, she did a short term voluntary work for Pariyavaran Mitra, an Ahmedabad based NGO. Currently she is working in Vastu Shilpa Consultants as a Planner under Mr. Balkrishna Vithaldas Doshi, an architect, academician, educator and institution builder. http://www.ifpgujarat.gov.in/portal/jsp/welcome.jsp 